\title{
$\begin{array}{ll}\text { Research Square } & \begin{array}{l}\text { Preprints are preliminary reports that have not undergone peer review. } \\ \text { They should not be considered conclusive, used to inform clinical practice, } \\ \text { or referenced by the media as validated information. }\end{array}\end{array}$
}

\section{The Clinical Desire for Pressurized Intraperitoneal Aerosol Chemotherapy in South Korea: An Electronic Survey-based Study}

\author{
Eun Ji Lee \\ Seoul National University College of Medicine \\ Soo Jin Park \\ Seoul National University College of Medicine \\ Jaehee Mun \\ Seoul National University College of Medicine \\ Haerin Paik \\ Seoul National University College of Medicine \\ Jeesun Lee \\ Seoul National University College of Medicine \\ Aeran Seol \\ Seoul National University College of Medicine \\ Junhwan Kim \\ Seoul National University College of Medicine \\ Nara Lee \\ CHA Gangnam Medical Center \\ Suk-Joon Chang \\ Ajou University School of Medicine \\ Hee Seung Kim ( $\nabla$ bboddi0311@gmail.com ) \\ Seoul National University College of Medicine
}

\section{Research Article}

Keywords: Pressurized intraperitoneal aerosol chemotherapy, peritoneal metastasis, survey

Posted Date: March 11th, 2021

DOI: https://doi.org/10.21203/rs.3.rs-272689/v1

License: (9) (1) This work is licensed under a Creative Commons Attribution 4.0 International License. Read Full License

Version of Record: A version of this preprint was published at Anticancer Research on December 29th, 2021. See the published version at https://doi.org/10.21873/anticanres.15494. 


\section{Abstract}

Background: Pressurized intraperitoneal aerosol chemotherapy (PIPAC) is effective for treating peritoneal metastasis. However, it is currently used in the limited areas. Thus, we performed a survey to evaluate the clinical desire for PIPAC in South Korea, one of the many countries where PIPAC has not yet been introduced.

Methods: We performed an online survey between November and December 2019. The questionnaire consisted of 20 questions, which were divided into comprehensive, procedure, and cost inquiries including five, 13 and two questions, respectively.

Results: A total of 164 respondents who answered the questionnaire. Among respondents, 41.7-50\% majoring in ovarian cancer, pseudomyxoma peritonei, and malignant mesothelioma preferred PIPAC for the curative treatment of primary diseases, whereas 32.7-33.3\% majoring in colorectal and hepatobiliary cancers chose it for the palliative treatment of recurrent diseases. Moreover, $66.7-95.2 \%$ considered PIPAC appropriate for the cancers the specialized in, and 76-78.7\% expected a treatment response of more than $50 \%$ and considered grade 1 or 2 minor surgical complications acceptable. Finally, most of the respondents answered the reasonable costs to purchase and implement PIPAC once at between 1,000,000-5,000,000 KRW.

Conclusions: This surgery may reflect on the availability, scope, and reasonable cost of PIPAC treatment in South Korea for introducing PIPAC.

\section{Background}

Peritoneal metastasis (PM) is commonly accompanied by a variety of solid tumors showing drug resistance to intravenous (IV) chemotherapy, which leads to a poor prognosis [1-3]. To try to overcome the limitations of IV chemotherapy, the effects and safety of intraperitoneal (IP) chemotherapy and hyperthermic intraperitoneal chemotherapy (HIPEC) have been investigated in solid tumor patients with PM. However, the effects of these therapies are still controversial [4-7], and renal and hepatic toxicities, a lack of relevant IP administration cycles and the required one-time administration after cytoreductive surgery are considered as disadvantages in IP chemotherapy and HIPEC [8].

On the other hand, pressurized intraperitoneal aerosol chemotherapy (PIPAC) delivers chemotherapeutic agents as an aerosol formed by a high-pressure injector at room temperature. Chemotherapeutic agents equivalent to $10 \%$ of those used in IV chemotherapy are effectively spread diffusely throughout the abdominal cavity by PIPAC, but tissue concentrations are maintained up to 200 times that of IV chemotherapy [9]. Moreover, PIPAC can be conducted repeatedly with more diffuse distribution, deeper penetration, and fewer toxicities than IP chemotherapy and HIPEC $[10,11]$. Nevertheless, PIPAC is currently considered primarily a palliative treatment [12] and is only available in the limited areas including European countries and Singapore [13].

A survey evaluating the clinical application and scope of PIPAC in countries where PIPAC has not been introduced is essential to establish the required medical foundation for future introduction. Thus, we performed a survey of surgical oncologists related to PIPAC to evaluate the clinical desire for PIPAC in South Korea.

\section{Methods}

\section{Participation}

This study was approved by the Institutional Review Board of Seoul National University Hospital in advance (No. 1907-054-104). We surveyed surgical oncologists from the following four societies between November and December 2019: the Korean Society of Gynecologic Oncology (http://www.sgo.or.kr/); the Korean Society of Surgical Oncology (http://www.sisso.or.kr/); the Korean Surgical Society (https://www.surgery.or.kr/); and the Korean Association of Hepato-Biliary-Pancreatic Surgery (http://www.kahbps.or.kr/).

\section{Study design}

The questionnaire consisted of 20 questions related to PIPAC, which were divided into the following categories: comprehensive inquiry (five questions), procedure inquiry (13 questions), and cost inquiry (two questions). The comprehensive inquiry included the following questions: How long do you have experience in treating solid tumors with PM as a surgical oncologist; what kind of hospital do you belong to; what types of solid tumors with PM do you treat mainly; how many solid tumor patients with PM do you treat annually; and what type of treatment do you approach for treating solid tumors with PM.

Moreover, the procedure inquiry included questions as follows: if you apply PIPAC for treating solid tumors with PM, what point in the course of disease progression would you consider using PIPAC; when you consider PIPAC for treating primary diseases, to what extent of disease would you consider applying PIPAC; when considering PIPAC for treating primary diseases with PM, would you consider neoadjuvant chemotherapy before PIPAC; what types of solid tumors with PM do you think that PIPAC can be applied to; do advantages such as high 
concentration in tissues with less drug and lower toxicities factor into the decision to use PIPAC; what factors do you think must preceded PIPAC introduction; what types and severities of complications would be considered reasonable from using PIPAC; do you think that it is appropriate to implement PIPAC repeatedly; do you think general anesthesia for 30 minutes to two hours is acceptable for performing PIPAC; what treatment response percentage would you expect from using PIPAC; what is the most critical factor that hinders the proper effect of PIPAC; and what do you think is the current level of evidence for the effects of PIPAC. Finally, the cost inquiry included questions about the reasonable cost of purchasing and implementing PIPAC (Table 1).

\section{Statistical analysis}

This survey was taken through the Elimnet Corporation (https://www.nownsurvey.com/), a commercially available web-based survey platform. All categorical variables were analyzed using the Chi-squared or Fisher's exact test. For the statistical analyses, we used SPSS software version 21.0 (SPSS Inc., Chicago, IL, USA).

This study was carried out in accordance with relevant guidelines.te the clinical desire for PIPAC in South Korea.

\section{Results}

\section{Comprehensive inquiry}

A total of 164 respondents answered the questionnaire, and 62 (37.8\%), 55 (33.5\%), 52 (31.7\%), 48 (29.3\%), 27 (16.5\%), and four respondents (2.4\%) treated PM accompanied by ovarian cancer, gastric cancer, colorectal cancer, pseudomyxoma peritonei, hepatobiliary cancer, malignant mesothelioma, and others.

About $60 \%$ of the respondents had more than ten years of experience and worked at university hospitals. Moreover, about $40 \%$ of the respondents said they treated more than ten solid tumor patients with PM annually and take a multidisciplinary treatment approach. However, there were no differences in periods of experience, working hospitals, and numbers of patients treated annually among the various surgical oncologists. In terms of treatment approach, the respondents majoring in gastric cancer (41.8\%), colorectal cancer (50\%), pseudomyxoma peritonei (37.5\%), and hepatobiliary cancer (33.3\%) preferred the multidisciplinary approach. In contrast, those majoring in ovarian cancer (33.9\%) and malignant mesothelioma (44.4\%) chose to plan their treatment by themselves (Table 2).

\section{Procedure inquiry}

In relation to the course of disease progression and the suitable point for PIPAC, $41.7-50 \%$ of respondents majoring in ovarian cancer, pseudomyxoma peritonei, and malignant mesothelioma preferred PIPAC as a curative treatment for primary diseases, whereas 32.7-33.3\% of those majoring in colorectal and hepatobiliary cancers preferred PIPAC as a palliative treatment for recurrent diseases.

Moreover, $65.5 \%$ of respondents answered that advanced-stage disease among primary diseases was suitable for applying PIPAC and 55.2\% would consider neoadjuvant chemotherapy before PIPAC. In particular, 66.7-95.2\% of respondents answered that the cancers they majored in were appropriate for PIPAC, and $87.2 \%$ considered the advantages of high concentration in tissues and lower toxicity as decisive factors for choosing PIPAC. However, 65.5\% of respondents considered results from randomized trials prerequisite for introducing PIPAC. Approximately $70 \%$ of respondents stated that they expected a treatment response of more than $50 \%$ through repeated implementation of PIPAC, and that grade 1 or 2 minor surgical complications were acceptable. About $60 \%$ of respondents answered that the patient's general status was the most important factor hindering the effect of PIPAC, and that the current level of evidence for the therapeutic effects of PIPAC was low.

However, there were no differences in the extents of primary diseases considered suitable for PIPAC treatment, the potential need for neoadjuvant chemotherapy, the decisive factors for using PIPAC, the prerequisites for introducing PIPAC, types and severities of tolerable complications, acceptability for implementing PIPAC under general anesthesia, and the expected percentage of treatment response among the various surgical oncologists (Table 3 ).

\section{Cost inquiry}

Most respondents answered that the reasonable cost to purchase and implement PIPAC once was between 1,000,000-5,000,000 KRW. There were no differences in the reasonable expenses to purchase and implement PIPAC among the various surgical oncologists (Table 4).

\section{Discussion}

This study was conducted to evaluate the clinical desire for PIPAC in South Korea, one of the countries where PIPAC has not yet been introduced. Through our survey, we identified the potential availability and scope of PIPAC, the expected effects and toxicity, and the expected 
reasonable cost of PIPAC in South Korea.

Although PIPAC is readily used to treat PM in Europe, its use does not come without concerns. First, the relevant studies are heterogeneous concerning patients and clinical indications. Second, the assessments of treatment response differed considerably among the relevant studies. Third, the appropriate endpoints to evaluate the effect of PIPAC, such as survival, quality of life, and ascites control are ambiguous [12]. In the absence of randomized controlled trials, the clinical desire for PIPAC is expected to differ according to the medical environment of each country.

We found that the availability and scope of PIPAC were different among different types of Korean surgical oncologists. Many respondents majoring in ovarian cancer, pseudomyxoma peritonei, and malignant mesothelioma preferred PIPAC for the curative treatment of primary diseases. In contrast, those majoring in colorectal and hepatobiliary cancers chose PIPAC for the palliative treatment of recurrent diseases. These findings are similar to the results from studies related to IP chemotherapy and HIPEC. In these studies, IP chemotherapy and HIPEC improved the prognosis of ovarian cancer [6, 7], pseudomyxoma peritonei [14, 15], and malignant mesothelioma [16, 17]. In contrast, they did not show any definitive effects for treating colorectal and hepatobiliary cancers $[4,18]$. This suggests Korean surgical oncologists may consider applying PIPAC in conditions similar to those that warrant IP chemotherapy and HIPEC.

Despite these differences, $66.7-95.2 \%$ of respondents considered the cancers they majored in appropriate for PIPAC. Moreover, about 70\% expected a treatment response of more than $50 \%$ through repeated implementation of PIPAC and considered grade 1 or 2 minor surgical complications acceptable. These findings are in line with data from previous studies where the rate of clinical response was $36-80 \%$ and grade 3 or 4 adverse events were observed in only 12-15\% of procedures [12]. These data suggest that the medical needs of Korean oncologists prior to the introduction of PIPAC are likely similar to those of their European counterparts.

Furthermore, what was considered the reasonable costs to purchase and implement PIPAC once was between 1,000,000-5,000,000 KRW, equivalent to about $1,000-5,000$ USD. This is about $20-50 \%$ of the cost of implementing HIPEC and about $5-10 \%$ of the cost for purchasing it in South Korea, which seemed to be determined by considering the repeated implementation of PIPAC. However, these costs will change over time with new domestic medical devices and the status of insurance markets.

All studies have limitations and ours is no exception. First, the number of specialists who could reply appropriately to this survey from each society could not be confirmed due to the Personal Information Protection Act. Considering the e-mail was sent to all members including residents, general doctors, and specialists, we could not estimate the response rates of only specialists in this study. Second, this survey was conducted exclusively on surgical oncologists. For more meaningful results, the survey should also be performed on medical oncologists who treat solid tumors with PM. Third, it may be unreasonable to consider these results similar to those from other countries where PIPAC has not been introduced because the medical environment may be very different.

\section{Conclusions}

This is the first study to investigate the clinical desire for PIPAC in countries where PIPAC has not yet been introduced. Based on the results from this study, we believe that the introduction of PIPAC will help to further establish the availability, scope, and reasonable cost of PIPAC treatment.

\section{Declarations}

\section{Acknowledgments}

We thank all members of the Koran Society of Gynecologic Oncology, the Korean Society of Surgical Oncology, the Korean Surgical Society, and the Korean Association of Hepato-Biliary-Pancreatic Surgery for cooperating in this survey. Moreover, we sincerely appreciate Dalim Medical Corp. for their collaborative work.

\section{Authors' contributions}

EJL: Data curation, Formal analysis, Investigation, Writing - original draft. SJP: Data curation, Formal analysis, Investigation. JM: Data curation, Investigation. HP: Data curation, Investigation. JL: Data curation, Investigation. AS: Data curation. JK: Data curation, Investigation. NL: Data curation, Investigation. SJC: Conceptualization, Data curation, Formal analysis, Investigation, Supervision, Writing - original draft, Writing - review \& editing. HSK: Conceptualization, Data curation, Formal analysis, Investigation, Supervision, Writing - original draft, Writing review \& editing.

\section{Funding}


This research was supported by grants from Seoul National University (No. 800-20170249, 800-20180201, 800-20190437) and Seoul National University Hospital (No. 06-20173250) supported this research.

\section{Availability of data and materials}

The dataset analyzed during the current study are available from the corresponding author on reasonable request, because the survey was conducted with guaranteed anonymity.

\section{Ethics approval and consent to participate}

Seoul National University Hospital Institutional Review Board (IRB) approved this study (No. 1907-054-104). The IRB waived the participants' consent. However, prior to the survey, consent to participation in the study and utilization of the survey results was additionally confirmed, and through this, it was confirmed that written consent was replaced.

\section{Consent for publication}

Not applicable.

\section{Conflicts of Interest}

The authors report no conflicts of interest.

\section{Abbreviations}

PIPAC: Pressurized intraperitoneal aerosol chemotherapy; PM: Peritoneal metastasis; IV: Intravenous; IP: Intraperitoneal; HIPEC: Hyperthermic intraperitoneal chemotherapy

\section{References}

1. Lambert LA. Looking up: Recent advances in understanding and treating peritoneal carcinomatosis. CA Cancer J Clin. 2015;65:284-98.

2. Coccolini F, Gheza F, Lotti M, Virzi S, lusco D, Ghermandi C, et al. Peritoneal carcinomatosis. World J Gastroenterol. 2013;19:6979-94.

3. Halkia E, Spiliotis J, Sugarbaker P. Diagnosis and management of peritoneal metastases from ovarian cancer. Gastroenterol Res Pract. 2012;2012:541842.

4. Klaver CEL, Wisselink DD, Punt CJA, Snaebjornsson P, Crezee J, Aalbers AGJ, et al. Adjuvant hyperthermic intraperitoneal chemotherapy in patients with locally advanced colon cancer (COLOPEC): a multicentre, open-label, randomised trial. Lancet Gastroenterol Hepatol. 2019;4:761-70.

5. Ishigami H, Fujiwara Y, Fukushima R, Nashimoto A, Yabusaki H, Imano M, et al. Phase III Trial Comparing Intraperitoneal and Intravenous Paclitaxel Plus S-1 Versus Cisplatin Plus S-1 in Patients With Gastric Cancer With Peritoneal Metastasis: PHOENIX-GC Trial. J Clin Oncol. 2018;36:1922-9.

6. van Driel WJ, Koole SN, Sikorska K, Schagen van Leeuwen JH, Schreuder HWR, Hermans RHM, et al. Hyperthermic Intraperitoneal Chemotherapy in Ovarian Cancer. N Engl J Med. 2018;378:230-40.

7. Armstrong DK, Bundy B, Wenzel L, Huang HQ, Baergen R, Lele S, et al. Intraperitoneal cisplatin and paclitaxel in ovarian cancer. N Engl J Med. 2006;354:34-43.

8. Kim M, Suh DH, Lee KH, Eom KY, ToftdahI NG, Mirza MR, et al. Major clinical research advances in gynecologic cancer in 2018. J Gynecol Oncol. 2019;30:e18.

9. Solass W, Kerb R, Murdter T, Giger-Pabst U, Strumberg D, Tempfer C, et al. Intraperitoneal Chemotherapy of Peritoneal Carcinomatosis Using Pressurized Aerosol as an Alternative to Liquid Solution: First Evidence for Efficacy. Ann Surg Oncol. 2014;21:553-9.

10. Larbre V, Alyami M, Mercier F, Vantard N, Bonnefoy I, Opsomer MA, et al. No Renal Toxicity After Repeated Treatment with Pressurized Intraperitoneal Aerosol Chemotherapy (PIPAC) in Patients with Unresectable Peritoneal Metastasis. Anticancer Res. 2018;38:6869-75.

11. Nadiradze G, Horvath P, Sautkin Y, Archid R, Weinreich FJ, Konigsrainer A, et al. Overcoming Drug Resistance by Taking Advantage of Physical Principles: Pressurized Intraperitoneal Aerosol Chemotherapy (PIPAC). Cancers (Basel). 2019;12:34.

12. Alyami M, Hubner M, Grass F, Bakrin N, Villeneuve L, Laplace N, et al. Pressurised intraperitoneal aerosol chemotherapy: rationale, evidence, and potential indications. Lancet Oncol. 2019;20:e368-77.

13. De Andrade JP, Warner SG, Fong Y. Treatment of metastatic colorectal cancer: innovations in surgical techniques. J Surg Oncol. 2019;119:653-9. 
14. Chua TC, Moran BJ, Sugarbaker PH, Levine EA, Glehen O, Gilly FN, et al. Early- and long-term outcome data of patients with pseudomyxoma peritonei from appendiceal origin treated by a strategy of cytoreductive surgery and hyperthermic intraperitoneal chemotherapy. J Clin Oncol. 2012;30:2449-56.

15. Klaver YL, Chua TC, Verwaal VJ, de Hingh IH, Morris DL. Secondary cytoreductive surgery and peri-operative intraperitoneal chemotherapy for peritoneal recurrence of colorectal and appendiceal peritoneal carcinomatosis following prior primary cytoreduction. $\mathrm{J}$ Surg Oncol. 2013;107:585-90.

16. Yan TD, Deraco M, Baratti D, Kusamura S, Elias D, Glehen O, et al. Cytoreductive surgery and hyperthermic intraperitoneal chemotherapy for malignant peritoneal mesothelioma: multi-institutional experience. J Clin Oncol. 2009;27:6237-42.

17. Kyang LS, Alzahrani NA, Valle SJ, Rahman MK, Arrowaili A, Liauw W, et al. Long-term survival outcomes of cytoreductive surgery and perioperative intraperitoneal chemotherapy: Single-institutional experience with 1225 cases. J Surg Oncol. 2019;120:794-802.

18. Randle RW, Levine EA, Clark CJ, Stewart JH, Shen P, Votanopoulos KI. Cytoreductive surgery with hyperthermic intraperitoneal chemotherapy for gallbladder cancer: a retrospective review. Am Surg. 2014;80:710-3.

\section{Tables}

e 1. Questionnaire related to pressurized intraperitoneal aerosol chemotherapy for surgical oncologists in South Korea 


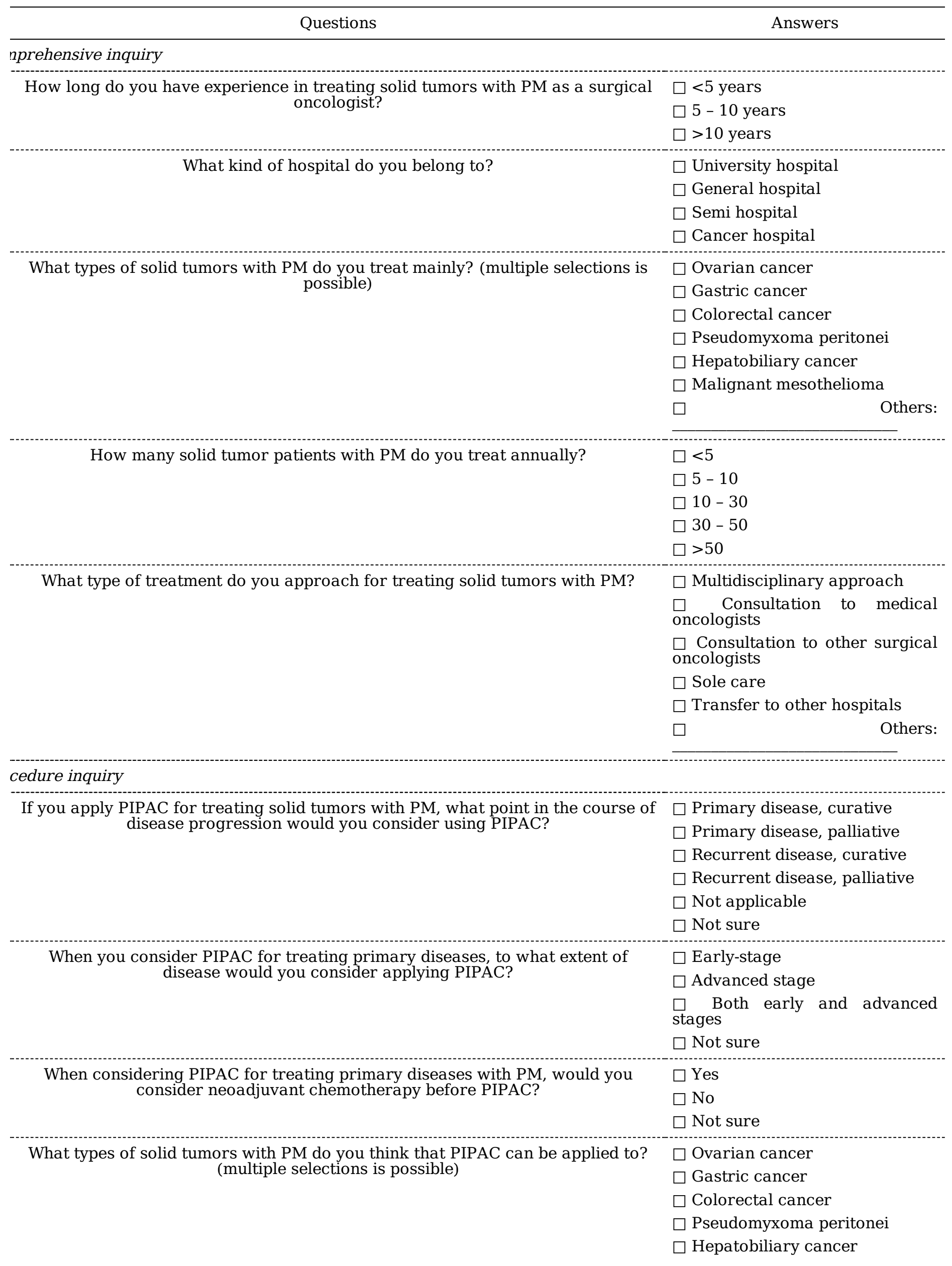




\begin{tabular}{|c|c|}
\hline $\begin{array}{c}\text { Do advantages such as high concentration in tissues with less drug and lower } \\
\text { toxicities factor into the decision to use PIPAC? }\end{array}$ & $\begin{array}{l}\square \text { Yes } \\
\square \text { No } \\
\square \text { Not sure }\end{array}$ \\
\hline \multirow[t]{5}{*}{ What factors do you think must be preceded PIPAC introduction? } & $\begin{array}{l}\square \text { Updates of treatment } \\
\text { guidelines }\end{array}$ \\
\hline & $\begin{array}{l}\square \text { Reports of results from } \\
\text { randomized trials }\end{array}$ \\
\hline & $\begin{array}{l}\square \text { Collaboration with specialists } \\
\text { for IP chemotherapy }\end{array}$ \\
\hline & $\begin{array}{l}\square \text { Reduction of complications } \\
\text { related to IP chemotherapy }\end{array}$ \\
\hline & $\square$ Others: \\
\hline \multirow[t]{4}{*}{$\begin{array}{c}\text { PIPAC is expected to have fewer complications than other types of IP } \\
\text { chemotherapy. But all treatments have complications and PIPAC is no exception. } \\
\text { What level of complications would you consider using PIPAC? }\end{array}$} & $\begin{array}{l}\square \text { Minor surgical complications } \\
\text { such as postoperative pain, } \\
\text { infection, and minor bleeding }\end{array}$ \\
\hline & $\begin{array}{l}\square \text { Major surgical complications } \\
\text { such as perforation and leakage } \\
\text { at anastomotic sites }\end{array}$ \\
\hline & $\square$ Hematologic toxicities \\
\hline & $\square$ Non-hematologic toxicities \\
\hline \multirow{5}{*}{$\begin{array}{c}\text { What severity of complication from PIPAC would you consider using PIPAC at? } \\
\text { (based on the CTCAE version 5.0) }\end{array}$} & $\square$ Grade 1 \\
\hline & $\square$ Grade 2 \\
\hline & $\square$ Grade 3 \\
\hline & $\begin{array}{l}\square \text { Possible regardless } \\
\text { complications }\end{array}$ \\
\hline & $\begin{array}{l}\square \quad \text { Impossible regardless of } \\
\text { complications }\end{array}$ \\
\hline
\end{tabular}

PIPAC is known to be repeated an average of four to six cycles to maximize the treatment response.

Do you think that it is appropriate to implement PIPAC repeatedly? $\square$ Acceptable if effective

$\square$ Willing to use it if reduced cycles

$\square$ Possible if only one cycle

Not sure

$\square$ Acceptable if patients are stable two hours.

Do you think general anesthesia for 30 minutes to two hours is acceptable for performing PIPAC?

\section{stable}

$\square$ Acceptable if local or spinal anesthesia

$\square$ Impossible if general anesthesia is required every cycle

$\square$ Not sure

$\begin{array}{cc}\text { According to the research results, the response rate of PIPAC is known to range } & \square>80 \% \\ \text { from } 20 \% \text { to } 80 \% . & \square>50 \% \\ \text { What treatment response percentage would you expect from using PIPAC? } & \square>20 \% \\ & \begin{array}{c}\text { Possible regponse rates } \\ \text { respless of }\end{array}\end{array}$

What is the most critical factor that hinders the proper effect of PIPAC?
Performance status of patients Suboptimal debulking surgery Burden of repetitive surgery Use of agents resistant to IV chemotherapy

Others: 
$\square$ High level, and effective

$\square$ Not sure

t inquiry

What do you think is the reasonable cost to purchase a medical device for PIPAC?

$\square<1,000,000 \mathrm{KRW}$
$\square 1,000,000-5,000,000 \mathrm{KRW}$
$\square 5,000,000-10,000,000 \mathrm{KRW}$
$\square 10,000,000-50,000,000 \mathrm{KRW}$
$\square>50,000,000 \mathrm{KRW}$
$\square<1,000,000 \mathrm{KRW}$
$\square 1,000,000-5,000,000 \mathrm{KRW}$
$\square 5,000,000-10,000,000 \mathrm{KRW}$
$\square>10,000,000 \mathrm{KRW}$

eviations: CTCAE, Common Terminology Criteria for Adverse Events; IP, intraperitoneal; IV, intravenous; PIPAC, surized intraperitoneal aerosol chemotherapy; PM, peritoneal metastasis.

ble 2. Answers to the comprehensive inquiry 


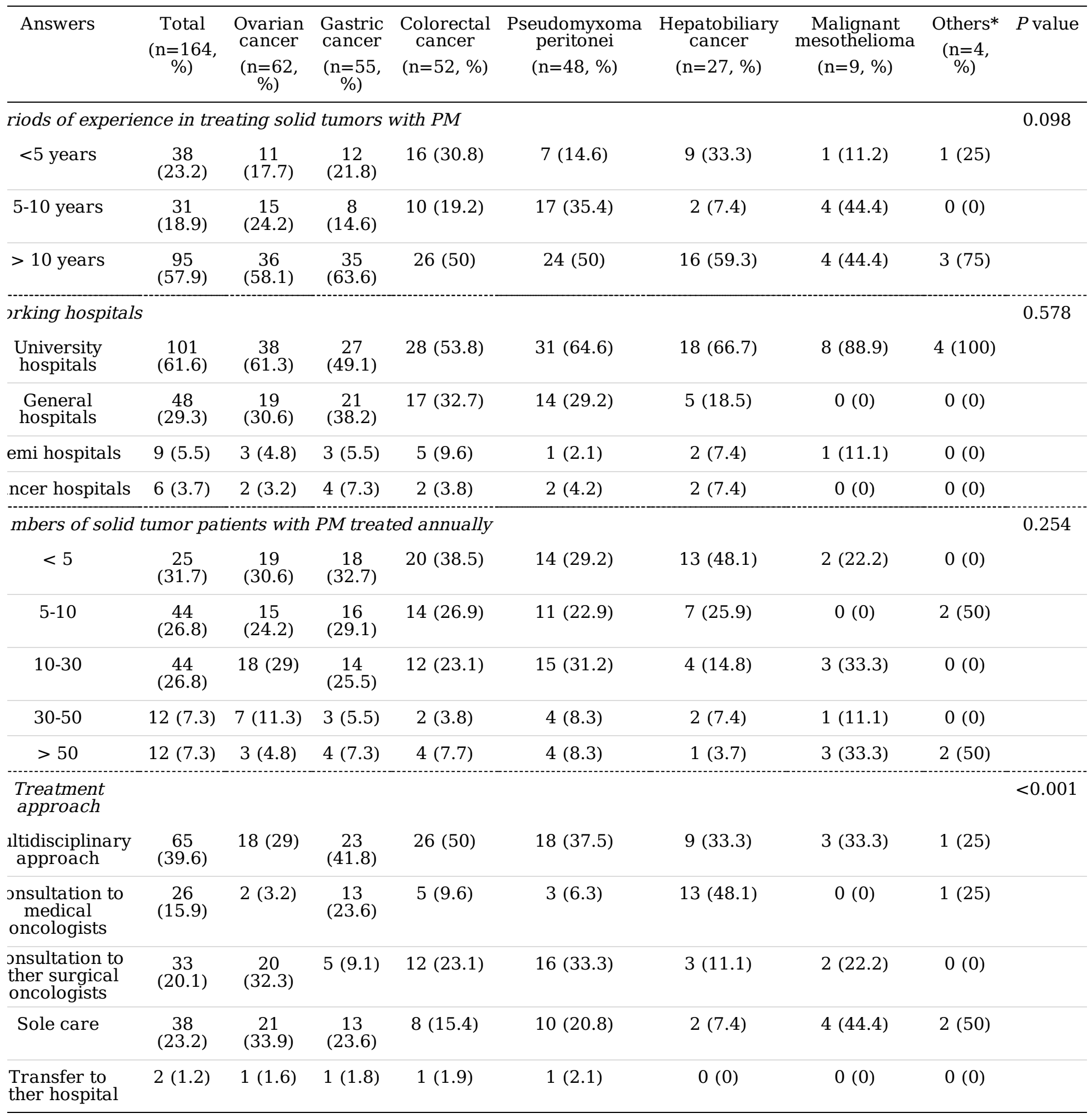

Ireviations: PIPAC, pressurized intraperitoneal aerosol chemotherapy; PM, peritoneal metastasis.

rvix and uterine cancers $(n=1)$; cervical cancer and peritoneal metastasis with other origins $(n=2)$; cervical cancer and coma $(n=1)$.

ble 3. Answers to the procedure inquiry 


\begin{tabular}{|c|c|c|c|c|c|c|c|c|c|}
\hline Answers & $\begin{array}{c}\text { Total } \\
(\mathrm{n}=164 \\
\%)\end{array}$ & $\begin{array}{c}\text { Ovarian } \\
\text { cancer } \\
(\mathrm{n}=62 \\
\%)\end{array}$ & $\begin{array}{c}\text { Gastric } \\
\text { cancer } \\
(\mathrm{n}=55 \\
\%)\end{array}$ & $\begin{array}{c}\text { Colorectal } \\
\text { cancer } \\
(n=52, \%)\end{array}$ & $\begin{array}{c}\text { Pseudomyxoma } \\
\text { peritonei } \\
(\mathrm{n}=48, \%)\end{array}$ & $\begin{array}{c}\text { Hepatobiliary } \\
\text { cancer } \\
(\mathrm{n}=27, \%)\end{array}$ & $\begin{array}{c}\text { Malignant } \\
\text { mesothelioma } \\
(\mathrm{n}=9, \%)\end{array}$ & $\begin{array}{l}\text { Others* } \\
(\mathrm{n}=4 \\
\%)\end{array}$ & $P$ value \\
\hline \multicolumn{9}{|c|}{ ints in the course of disease progression suitable to PIPAC } & 0.018 \\
\hline $\begin{array}{l}\text { Primary } \\
\text { disease, } \\
\text { curative }\end{array}$ & $\begin{array}{c}58 \\
(35.4)\end{array}$ & $31(50)$ & $\begin{array}{c}17 \\
(30.9)\end{array}$ & $8(15.4)$ & $20(41.7)$ & $4(14.8)$ & $4(44.4)$ & $0(0)$ & \\
\hline $\begin{array}{l}\text { Primary } \\
\text { disease, } \\
\text { palliative }\end{array}$ & $\begin{array}{c}27 \\
(16.5)\end{array}$ & $5(8.1)$ & $\begin{array}{c}12 \\
(21.8)\end{array}$ & $14(26.9)$ & $3(6.3)$ & $8(29.6)$ & $2(22.2)$ & $0(0)$ & \\
\hline $\begin{array}{l}\text { Recurrent } \\
\text { disease, } \\
\text { curative }\end{array}$ & $18(11)$ & $6(9.7)$ & $\begin{array}{c}7 \\
(12.7)\end{array}$ & $10(19.2)$ & $7(14.6)$ & $2(7.4)$ & $0(0)$ & $0(0)$ & \\
\hline $\begin{array}{l}\text { Recurrent } \\
\text { disease, } \\
\text { palliative }\end{array}$ & $\begin{array}{c}47 \\
(28.7)\end{array}$ & $\begin{array}{c}15 \\
(24.2)\end{array}$ & $\begin{array}{c}17 \\
(30.9)\end{array}$ & $17(32.7)$ & $14(27.1)$ & $9(33.3)$ & $2(22.2)$ & $3(75)$ & \\
\hline st applicable & $6(3.7)$ & $3(4.8)$ & $1(1.8)$ & $1(1.9)$ & $2(4.2)$ & $1(3.7)$ & $1(11.1)$ & $0(0)$ & \\
\hline Not sure & $8(4.9)$ & $2(3.2)$ & $1(1.8)$ & $2(3.8)$ & $3(6.3)$ & $3(11.1)$ & $0(0)$ & $1(25)$ & \\
\hline \multicolumn{9}{|c|}{ tents of primary diseases suitable to PIPAC } & 0.682 \\
\hline Early stage & $4(6.9)$ & $3(9.7)$ & $1(5.9)$ & $0(0)$ & $1(5)$ & $0(0)$ & $0(0)$ & $0(0)$ & \\
\hline $\begin{array}{l}\text { Advanced } \\
\text { stage }\end{array}$ & $\begin{array}{c}38 \\
(65.5)\end{array}$ & $\begin{array}{c}18 \\
(58.1)\end{array}$ & $\begin{array}{c}13 \\
(76.5)\end{array}$ & $7(87.5)$ & $15(75)$ & $2(50)$ & $4(100)$ & $0(0)$ & \\
\hline $\begin{array}{l}\text { th early and } \\
\text { advanced } \\
\text { stages }\end{array}$ & $\begin{array}{c}16 \\
(27.6)\end{array}$ & $\begin{array}{c}10 \\
(32.3)\end{array}$ & $\begin{array}{c}3 \\
(17.6)\end{array}$ & $1(12.5)$ & $4(20)$ & $2(50)$ & $0(0)$ & $0(0)$ & \\
\hline \multicolumn{9}{|c|}{ ed for neoadjuvant chemotherapy before PIPAC } & 0.303 \\
\hline Yes & $\begin{array}{c}32 \\
(55.2)\end{array}$ & $\begin{array}{c}13 \\
(41.9)\end{array}$ & $\begin{array}{c}13 \\
(79.5)\end{array}$ & $6(75)$ & $12(60)$ & $2(50)$ & $1(25)$ & $0(0)$ & \\
\hline No & $\begin{array}{c}17 \\
(29.3)\end{array}$ & $\begin{array}{c}10 \\
(32.3)\end{array}$ & $\begin{array}{c}3 \\
(17.6)\end{array}$ & $2(25)$ & $6(30)$ & $2(50)$ & $2(50)$ & $0(0)$ & \\
\hline Not sure & $9(15.5)$ & $8(25.8)$ & $1(5.9)$ & $0(0)$ & $2(10)$ & $0(0)$ & $1(25)$ & $0(0)$ & \\
\hline \multicolumn{9}{|c|}{ pes of solid tumors with peritoneal neoplasms that PIPAC can be applied } & $<0.01$ \\
\hline arian cancer & $\begin{array}{l}123 \\
(75)\end{array}$ & $\begin{array}{c}59 \\
(95.2)\end{array}$ & $33(60)$ & 29 (55.8) & 39 (81.3) & $17(63)$ & 8 (88.9) & $0(0)$ & \\
\hline $\begin{array}{l}\text { Stomach } \\
\text { cancer }\end{array}$ & $82(50)$ & $\begin{array}{c}12 \\
(19.4)\end{array}$ & $\begin{array}{c}50 \\
(90.9)\end{array}$ & $33(63.5)$ & $19(39.6)$ & $13(48.1)$ & $7(77.8)$ & $0(0)$ & \\
\hline $\begin{array}{l}\text { Colorectal } \\
\text { cancer }\end{array}$ & $\begin{array}{c}93 \\
(56.7)\end{array}$ & $\begin{array}{c}20 \\
(32.3)\end{array}$ & $\begin{array}{c}40 \\
(72.7)\end{array}$ & 48 (92.3) & $24(50)$ & $16(59.3)$ & $6(66.7)$ & $0(0)$ & \\
\hline $\begin{array}{l}\text { eudomyxoma } \\
\text { peritonei }\end{array}$ & $\begin{array}{c}119 \\
(72.6)\end{array}$ & 49 (79) & $33(60)$ & 35 (67.3) & $43(89.6)$ & $16(59.3)$ & $6(66.7)$ & $0(0)$ & \\
\hline $\begin{array}{l}\text { epatobiliary } \\
\text { cancer }\end{array}$ & $\begin{array}{c}32 \\
(19.5)\end{array}$ & $9(14.5)$ & $\begin{array}{c}10 \\
(18.2)\end{array}$ & 11 (21.2) & $5(10.4)$ & $19(70.4)$ & $2(22.2)$ & $0(0)$ & \\
\hline $\begin{array}{l}\text { Malignant } \\
\text { esothelioma }\end{array}$ & $\begin{array}{c}50 \\
(30.5)\end{array}$ & $\begin{array}{c}20 \\
(32.3)\end{array}$ & $\begin{array}{c}15 \\
(27.3)\end{array}$ & $12(23.1)$ & $17(35.4)$ & $3(11.1)$ & $6(66.7)$ & $0(0)$ & \\
\hline
\end{tabular}

ssibility to consider the advantage of high concentration in tissues and fewer toxicities as decisive factors for 0.08 ing PIPAC

\begin{tabular}{ccccccccc} 
Yes & 143 & 52 & 52 & $47(90.4)$ & $38(79.2)$ & $24(88.9)$ & $5(55.6)$ & $2(50)$ \\
\hline No & $(87.2)$ & $(83.9)$ & $(94.5)$ & & & & & \\
\hline Not sure & $9(5.5)$ & $3(4.8)$ & $2(3.6)$ & $2(3.8)$ & $3(6.3)$ & $1(3.7)$ & $2(22.2)$ & $1(25)$ \\
\hline & $12(7.3)$ & $7(11.3)$ & $1(1.8)$ & $3(5.8)$ & $7(14.6)$ & $2(7.4)$ & $2(22.2)$ & $1(25)$
\end{tabular}




\begin{tabular}{|c|c|c|c|c|c|c|c|c|c|}
\hline $\begin{array}{l}\text { Update of } \\
\text { treatment } \\
\text { guidelines }\end{array}$ & $\begin{array}{c}34 \\
(20.7)\end{array}$ & $\begin{array}{c}15 \\
(24.2)\end{array}$ & $\begin{array}{c}10 \\
(18.2)\end{array}$ & $10(19.2)$ & $10(20.8)$ & $5(18.5)$ & $3(33.3)$ & $1(25)$ & \\
\hline $\begin{array}{l}\text { Reports of } \\
\text { esults from } \\
\text { andomized } \\
\text { trials }\end{array}$ & $\begin{array}{c}107 \\
(65.2)\end{array}$ & $\begin{array}{c}52 \\
(67.7)\end{array}$ & $33(60)$ & $34(65.4)$ & $30(62.5)$ & $17(63)$ & $6(66.7)$ & $2(50)$ & \\
\hline $\begin{array}{l}\text { ollaboration } \\
\text { th specialists } \\
\text { for IP } \\
\text { lemotherapy }\end{array}$ & $10(6.1)$ & $3(4.8)$ & $5(9.1)$ & $6(11.5)$ & $2(4.2)$ & $3(11.1)$ & $0(0)$ & $0(0)$ & \\
\hline $\begin{array}{l}\text { eduction of } \\
\text { smplications } \\
\text { elated to IP } \\
\text { lemotherapy }\end{array}$ & $13(7.9)$ & $2(3.2)$ & $\begin{array}{c}7 \\
(12.7)\end{array}$ & $2(3.8)$ & $6(12.5)$ & $2(7.4)$ & $0(0)$ & $1(25)$ & \\
\hline \multicolumn{8}{|c|}{ pes of tolerable complications considerable to use PIPAC } & & 0.94 \\
\hline $\begin{array}{l}\text { inor surgical } \\
\text { mplications }{ }^{\dagger}\end{array}$ & $\begin{array}{l}118 \\
(72)\end{array}$ & $44(71)$ & $\begin{array}{c}42 \\
(76.4)\end{array}$ & $36(69.2)$ & $38(79.2)$ & $19(70.4)$ & $7(77.8)$ & $3(75)$ & \\
\hline $\begin{array}{l}\text { ajor surgical } \\
\text { mplications }\end{array}$ & \multicolumn{8}{|c|}{ mplications ${ }^{\ddagger}$} & \\
\hline $\begin{array}{l}\text { Iematologic } \\
\text { toxicities }\end{array}$ & $23(14)$ & $\begin{array}{c}10 \\
(16.1)\end{array}$ & $\stackrel{8}{8}$ & $5(9.6)$ & $2(4.2)$ & $4(14.8)$ & $1(11.1)$ & $0(0)$ & \\
\hline $\begin{array}{l}\text { Non- } \\
\text { tematologic } \\
\text { toxicities }\end{array}$ & $5(3)$ & $1(1.6)$ & $1(1.8)$ & $3(5.8)$ & $2(4.2)$ & $1(3.7)$ & $0(0)$ & $0(0)$ & \\
\hline \multicolumn{9}{|c|}{ verities of tolerable complications considerable to use PIPAC (based on the CTCAE version 5.0) } & 0.65 \\
\hline Grade 1 & $\begin{array}{c}67 \\
(40.9)\end{array}$ & $\begin{array}{c}23 \\
(37.1)\end{array}$ & $\begin{array}{c}27 \\
(49.1)\end{array}$ & $20(38.5)$ & $22(45.8)$ & $15(55.6)$ & $5(55.6)$ & $3(75)$ & \\
\hline Grade 2 & $\begin{array}{c}62 \\
(37.8)\end{array}$ & $\begin{array}{c}24 \\
(38.7)\end{array}$ & $\begin{array}{c}18 \\
(32.7)\end{array}$ & $22(42.3)$ & $15(31.3)$ & $10(37)$ & $2(22.2)$ & $1(25)$ & \\
\hline Grade 3 & $\begin{array}{c}29 \\
(17.7)\end{array}$ & $\begin{array}{c}15 \\
(24.2)\end{array}$ & $\begin{array}{c}7 \\
(12.7)\end{array}$ & $8(15.4)$ & $9(18.8)$ & $1(3.7)$ & $2(22.2)$ & $0(0)$ & \\
\hline $\begin{array}{l}\text { Possible } \\
\text { əgardless of } \\
\text { mpplications }\end{array}$ & $6(3.7)$ & $0(0)$ & $3(5.5)$ & $2(3.8)$ & $2(4.2)$ & $1(3.7)$ & $0(0)$ & $0(0)$ & \\
\hline $\begin{array}{l}\text { Impossible } \\
\text { zgardless of } \\
\text { )mplications }\end{array}$ & $0(0)$ & $0(0)$ & $0(0)$ & $0(0)$ & $0(0)$ & $0(0)$ & $0(0)$ & $0(0)$ & \\
\hline \multicolumn{9}{|c|}{ ceptability for implementing PIPAC repeatedly } & $<0.01$ \\
\hline $\begin{array}{l}\text { cceptable if } \\
\text { effective }\end{array}$ & $\begin{array}{c}116 \\
(70.7)\end{array}$ & $\begin{array}{c}40 \\
(64.5)\end{array}$ & $\begin{array}{c}43 \\
(78.2)\end{array}$ & $37(71.2)$ & $36(75)$ & $19(70.4)$ & $7(77.8)$ & $0(0)$ & \\
\hline $\begin{array}{l}\text { lling to use it } \\
\text { if reduced } \\
\text { cycles }\end{array}$ & $\begin{array}{c}27 \\
(16.5)\end{array}$ & $9(14.5)$ & $\begin{array}{c}8 \\
(14.5)\end{array}$ & $10(19.2)$ & $4(8.3)$ & $5(18.5)$ & $0(0)$ & $0(0)$ & \\
\hline $\begin{array}{l}\text { 'ssible if only } \\
\text { one cycle }\end{array}$ & $14(8.5)$ & $9(14.5)$ & $2(3.6)$ & $2(3.8)$ & $5(10.4)$ & $3(11.1)$ & $1(11.1)$ & $4(100)$ & \\
\hline Not sure & $7(4.3)$ & $7(4.3)$ & $2(3.6)$ & $3(5.8)$ & $3(6.3)$ & $0(0)$ & $1(11.1)$ & $0(0)$ & \\
\hline \multicolumn{9}{|c|}{ ceptability for implementing PIPAC under general anesthesia } & 0.08 \\
\hline $\begin{array}{l}\text { cceptable if } \\
\text { atients are } \\
\text { stable }\end{array}$ & $\begin{array}{l}111 \\
(67.7)\end{array}$ & $\begin{array}{c}34 \\
(54.8)\end{array}$ & $\begin{array}{c}42 \\
(76.4)\end{array}$ & $36(69.2)$ & $34(70.8)$ & $21(77.8)$ & $5(55.6)$ & $4(100)$ & \\
\hline $\begin{array}{l}\text { cceptable if } \\
\text { cal or spinal } \\
\text { anesthesia }\end{array}$ & $\begin{array}{c}30 \\
(18.3)\end{array}$ & $\begin{array}{c}16 \\
(25.8)\end{array}$ & $\begin{array}{c}6 \\
(10.9)\end{array}$ & $11(21.2)$ & $9(18.8)$ & $3(11.1)$ & $0(0)$ & $0(0)$ & \\
\hline npossible if & $16(9.8)$ & $8(12.9)$ & $4(7.3)$ & $3(5.8)$ & $4(8.3)$ & $3(11.1)$ & $4(44.4)$ & $0(0)$ & \\
\hline
\end{tabular}


general

nesthesia is

quired every

cycle

\begin{tabular}{|c|c|c|c|c|c|c|c|c|c|}
\hline Not sure & $7(4.3)$ & $4(6.5)$ & $3(5.5)$ & $2(3.8)$ & $1(2.1)$ & $0(0)$ & $0(0)$ & $0(0)$ & \\
\hline \multicolumn{9}{|c|}{ eatment response percentage considerable for using PIPAC } & 0.94 \\
\hline$>80 \%$ & $\begin{array}{c}22 \\
(13.4)\end{array}$ & $9(14.5)$ & $\begin{array}{c}7 \\
(12.7)\end{array}$ & $11(21.2)$ & $5(10.4)$ & $4(14.8)$ & $1(11.1)$ & $0(0)$ & \\
\hline$>50 \%$ & $\begin{array}{c}119 \\
(72.6)\end{array}$ & $\begin{array}{c}41 \\
(66.1)\end{array}$ & $\begin{array}{c}39 \\
(70.9)\end{array}$ & $34(65.4)$ & $34(70.8)$ & $18(66.7)$ & $5(55.6)$ & $3(75)$ & \\
\hline$>20 \%$ & $\begin{array}{c}21 \\
(12.8)\end{array}$ & $\begin{array}{l}11 \\
(17.7)\end{array}$ & $\begin{array}{c}9 \\
(16.4)\end{array}$ & $6(11.5)$ & $7(14.6)$ & $5(18.5)$ & $3(33.3)$ & $1(25)$ & \\
\hline $\begin{array}{l}\text { Possible } \\
\text { əgardless of } \\
\text { sponse rates }\end{array}$ & $2(1.2)$ & $1(1.6)$ & $0(0)$ & $1(1.9)$ & $2(4.2)$ & $0(0)$ & $0(0)$ & $0(0)$ & \\
\hline \multicolumn{9}{|c|}{ e most impediment to the proper effectiveness of PIPAC } & 0.24 \\
\hline $\begin{array}{l}\text { əneral status } \\
\text { of patients }\end{array}$ & $\begin{array}{c}93 \\
(56.7)\end{array}$ & $\begin{array}{c}27 \\
(43.5)\end{array}$ & $\begin{array}{c}38 \\
(69.1)\end{array}$ & $35(67.3)$ & $30(62.5)$ & $18(66.7)$ & $6(66.7)$ & $4(100)$ & \\
\hline $\begin{array}{l}\text { Suboptimal } \\
\text { debulking } \\
\text { surgery }\end{array}$ & $\begin{array}{c}32 \\
(19.5)\end{array}$ & $\begin{array}{c}19 \\
(30.6)\end{array}$ & $5(9.1)$ & $6(11.5)$ & $6(12.5)$ & $4(14.8)$ & $0(0)$ & $0(0)$ & \\
\hline $\begin{array}{l}\text { le burden of } \\
\text { Jerforming } \\
\text { repetitive } \\
\text { surgery }\end{array}$ & $\begin{array}{c}29 \\
(17.8)\end{array}$ & $\begin{array}{c}13 \\
(21.1)\end{array}$ & $\begin{array}{c}8 \\
(14.5)\end{array}$ & $9(17.3)$ & $7(14.5)$ & $4(14.8)$ & $1(11.1)$ & $0(0)$ & \\
\hline $\begin{array}{l}\text { Ise of drugs } \\
\text { :Sistant to IV } \\
\text { lemotherapy }\end{array}$ & $5(3)$ & $1(1.6)$ & $3(5.5)$ & $1(1.9)$ & $2(4.2)$ & $0(0)$ & $1(11.1)$ & $0(0)$ & \\
\hline Others $\|$ & $5(3)$ & $2(3.2)$ & $1(1.8)$ & $1(1.9)$ & $3(6.3)$ & $1(3.7)$ & 1 (11.1) & $0(0)$ & \\
\hline \multicolumn{9}{|c|}{ vels of evidence for the effects of PIPAC } & 0.06 \\
\hline $\begin{array}{l}\text { sw level, and } \\
\text { ot effective }\end{array}$ & $\begin{array}{c}39 \\
(23.8)\end{array}$ & $\begin{array}{c}15 \\
(24.2)\end{array}$ & $\begin{array}{c}14 \\
(25.5)\end{array}$ & $9(17.3)$ & 8 (16.7) & $13(48.1)$ & $3(33.3)$ & $1(25)$ & \\
\hline $\begin{array}{l}\text { Jw level, but } \\
\text { effective }\end{array}$ & 64 (39) & $\begin{array}{c}21 \\
(33.9)\end{array}$ & $\begin{array}{c}26 \\
(47.3)\end{array}$ & $24(46.2)$ & $20(41.7)$ & $5(18.5)$ & $4(44.4)$ & $1(25)$ & \\
\hline $\begin{array}{l}\text { gh level, and } \\
\text { effective }\end{array}$ & $8(4.9)$ & $3(4.8)$ & $5(9.1)$ & $0(0)$ & $6(12.5)$ & $1(3.7)$ & 1 (11.1) & $0(0)$ & \\
\hline Not sure & $\begin{array}{c}53 \\
(32.3)\end{array}$ & $\begin{array}{c}23 \\
(37.1)\end{array}$ & $\begin{array}{c}10 \\
(18.2)\end{array}$ & 19 (36.5) & $14(29.2)$ & 8 (29.6) & 1 (11.1) & $2(50)$ & \\
\hline
\end{tabular}

rreviations: CTCAE, Common Terminology Criteria for Adverse Events; IP, intraperitoneal; IV, intravenous; PIPAC, ssurized intraperitoneal aerosol chemotherapy.

rvix and uterine cancers $(n=1)$; cervical cancer and peritoneal neoplasms with other origins $(n=2)$; cervical cancer and coma $(\mathrm{n}=1)$;

stoperative pain, infection and minor bleeding; ${ }^{\ddagger}$ perforation and leakage at anastomotic sites;

terogeneous distribution of drugs due to adhesion $(n=3)$, less effective in hematogenous or lymphatic metastasis $(n=1)$; risk bdominal compartment syndrome by pressurized intraperitoneal aerosol chemotherapy $(n=1)$

ble 4. Answers to the cost inquiry 


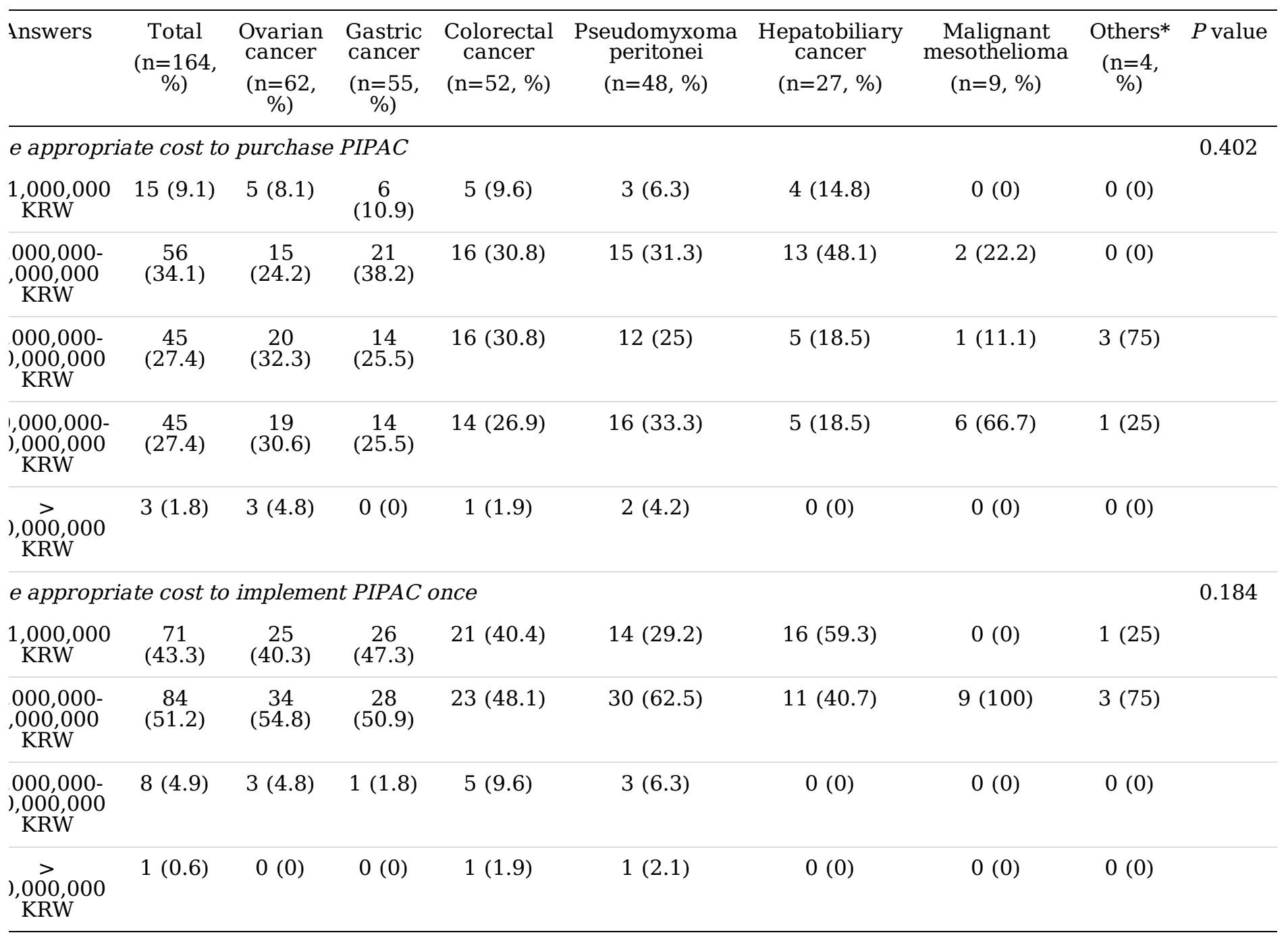

rreviation: KRW, Korean Won; PIPAC, pressurized intraperitoneal aerosol chemotherapy.

rvix and uterine cancers $(n=1)$; cervical cancer and peritoneal neoplasms with other origins ( $n=2)$; cervical cancer and soma $(n=1)$ 